care for those who need it most. Finally, this scheduling approach may preserve the bulk of physically and mentally healthy staff sorely needed to combat later effects of pandemic, which will have dire consequences for healthcare systems that have not made every effort to prevent intrainstitutional transmission.

\section{Acknowledgments. None.}

Financial support. No financial support was provided relevant to this article.

Conflicts of interest. M.Ć. and P.B. have received lecture honoraria from Lundbeck, Sandoz, Janssen, Pliva (Teva), and Alkaloid. A.K. has no conflicts of interest to declare.

\section{References}

1. Wu Z, McGoogan JM. Characteristics of and important lessons from the coronavirus disease 2019 (COVID-19) outbreak in China. JAMA 2020 [Epub ahead of print]. doi: 10.1001/jama.2020.2648.

2. Hick JL, Biddinger PD. Novel coronavirus and old lessons-preparing the health system for the pandemic. N Engl J Med 2020 [Epub ahead of print]. doi: 10.1056/NEJMp2005118.

3. Emanuel EJ, Persad G, Upshur R, et al. Fair allocation of scarce medical resources in the time of COVID-19. N Engl J Med 2020 [Epub ahead of print]. doi: 10.1056/NEJMsb2005114.
4. Lima CKT, Carvalho PMM, Lima IAAS, et al. The emotional impact of coronavirus 2019-nCoV (new Coronavirus disease). Psychiatry Res 2020;287:112915 [Epub ahead of print]. doi: 10.1016/j.psychres.2020. 112915.

5. Greenberg N, Docherty M, Gnanapragasam S, Wessely S. Managing mental health challenges faced by healthcare workers during covid-19 pandemic. BMJ 2020 Mar 26;368:m1211. doi: 10.1136/bmj.m1211.

6. Chopra V, Toner E, Waldhorn R, Washer L. How should US hospitals prepare for coronavirus disease 2019 (COVID-19)? Ann Intern Med 2020 Mar 11 [Epub ahead of print]. doi: 10.7326/M20-0907.

7. Xiang YT, Zhao YJ, Liu ZH, et al. The COVID-19 outbreak and psychiatric hospitals in China: managing challenges through mental health service reform. Int J Biol Sci 2020 Mar 15;16:1741-1744.

8. Chang, Xu H, Rebaza A, Sharma L, Dela Cruz CS. Protecting health-care workers from subclinical coronavirus infection. Lancet Respir Med 2020; 8(3):e13. doi: 10.1016/S2213-2600(20)30066-7.

9. Bearman G, Pryor R, Albert H, et al. Novel coronavirus and hospital infection prevention: preparing for the impromptu speech. Infect Control Hosp Epidemiol 2020;3:1-2 [Epub ahead of print]. doi: 10.1017/ ice.2020.55.

10. Gaur S, Dumyati G, Nace DA, Jump RLP. Unprecedented solutions for extraordinary times: helping long-term care settings deal with the COVID-19 pandemic. Infect Control Hosp Epidemiol 2020;30:1-8 [Epub ahead of print]. doi: 10.1017/ice.2020.98.

\title{
Bacterial and fungal infections in COVID-19 patients: A matter of concern
}

\author{
Pengcheng Zhou MD ${ }^{1,2}$, Zhenguo Liu MD², Yuhua Chen MSN ${ }^{1}$, Yinzong Xiao MD ${ }^{1,3}$, Xun Huang MD ${ }^{1}$ and Xue-Gong Fan MD \\ ${ }^{1}$ Xiangya Hospital, Central South University, Changsha, China, ${ }^{2}$ The Third Xiangya Hospital, Central South University, Changsha, China and ${ }^{3}$ Burnet Institute, \\ St Vincent's Hospital Melbourne, and University of Melbourne, Melbourne, Australia
}

To the Editor-Coronavirus disease 2019 (COVID-19) has become a pandemic. As of April 2, 2020, a total of 896,450 laboratoryconfirmed cases have been reported. The death toll from COVID-19 has soared quickly: 45,526 deaths have been reported globally, including 24,692 deaths in only a week (March 26, 2020, through April 2, 2020). ${ }^{1}$ Age, sequential organ failure assessment (SOFA) score, and D-dimer are the main prognostic factors of COVID-19 patients. ${ }^{2}$ The presence of bacterial and/or fungal secondary infection or coinfection is likely another important factor affecting mortality, and it has received inadequate attention.

Bacterial and fungal infections are common complications of viral pneumonia, especially in critically ill patients. They lead to increased need for intensive care and increased mortality. In influenza patients, bacterial coinfection occurs in $\sim 0.5 \%$ of healthy young individuals and at least $2.5 \%$ of older individuals. ${ }^{3} \mathrm{~A}$ systematic review revealed that $\sim 1$ in 4 H1N1 patients during the 2009 pandemic had a bacterial or fungi infection infection. ${ }^{4}$ Data regarding the bacterial or fungi infection in viral pneumonia led by

Author for correspondence: Xue-Gong Fan MD Or Xun Huang MD, E-mail: xgfan@ hotmail.com or huangxun224@126.com.

Cite this article: Zhou P, et al. (2020). Bacterial and fungal infections in COVID-19 patients: A matter of concern. Infection Control \& Hospital Epidemiology, 41: 1124-1125, https://doi.org/10.1017/ice.2020.156 coronavirus are limited. According to the cohort study report by Zhong Nanshan et al, ${ }^{5} 20$ of 90 severe acute respiratory syndrome (SARS) patients had secondary lower respiratory tract infections in 2003 , which accounted for $70.6 \%$ of those critical SARS patients who underwent an invasive operation. The pathogens causing secondary infections in SARS patients were diverse: negative bacilli were the most common but Candida was also common. ${ }^{5}$ Invasive pulmonary aspergillosis was another common complication secondary to influenza. ${ }^{6}$

Bacterial and fungal infections in COVID-19 patients have been inadequately investigated and reported thus far. Among the hundreds of articles published with clinical data, only a few have reported secondary infection, mostly without detailed pathogens (Table 1). Even in studies for which secondary infection data are available, the antibiotics use rate $(94 \%-100 \%)$ was much higher than the reported incidence of secondary infection $(10 \%-15 \%)^{2,7,8}$ In addition, the complication of bacterial or fungal infection was not included in the prognosis analysis in most published papers. Moreover, most of the current infection control protocols aim to prevent the transmission and cross infection by SARS-CoV-2, missing the prevention of bacterial or fungal secondary infection. In fact, secondary infection was found in $50 \%$ of nonsurviving COVID-19 patients. $^{2}$

Thus far, many diagnostic and prevention approaches to targeting complications in COVID-19 patients have been outlined in

(c) 2020 by The Society for Healthcare Epidemiology of America. All rights reserved. This is an Open Access article, distributed under the terms of the Creative Commons Attribution licence (http://creativecommons.org/licenses/by/4.0/), which permits unrestricted re-use, distribution, and reproduction in any medium, provided the original work is properly cited. 
Table 1. Secondary Infection or Coinfection in COVID-19 Patients

\begin{tabular}{|c|c|c|c|c|c|c|c|c|c|}
\hline \multicolumn{3}{|c|}{$\begin{array}{l}\text { Patients With Secondary Infection } \\
\text { or Coinfection, } \mathrm{n} / \mathrm{N}(\%)\end{array}$} & \multicolumn{3}{|c|}{$\begin{array}{c}\text { Antibiotics Use Rate, } \\
\mathrm{n} / \mathrm{N}(\%)\end{array}$} & \multicolumn{3}{|c|}{$\begin{array}{c}\text { Procalcitonin } \geq 0.25 \mathrm{ng} / \mathrm{mL} \text {, } \\
\mathrm{n} / \mathrm{N}(\%)\end{array}$} & \multirow[b]{2}{*}{ Reference } \\
\hline Total & Nonsurvivors & Survivors & Total & Nonsurvivors & Survivors & Total & Nonsurvivors & Survivors & \\
\hline $28 / 191(15)$ & $27 / 54(50)$ & $1 / 137(1)$ & $181 / 191$ (95) & $53 / 54$ (98) & $128 / 137$ (93) & $20 / 164(12)$ & $16 / 51(31)$ & $4 / 113(4)$ & Zhou et $\mathrm{al}^{2}$ \\
\hline $9 / 52(17)$ & $4 / 32(13)$ & $5 / 20(25)$ & 49/52 (94) & $30 / 32$ (94) & $19 / 20$ (95) & $\ldots$ & $\ldots$ & $\ldots$ & Yang et $\mathrm{al}^{8}$ \\
\hline $4 / 41$ (10) & $4 / 13(31)$ & $0 / 28(0)$ & $41 / 41(10)$ & $13 / 13(100)$ & $28 / 28(100)$ & $5 / 39(13)$ & $3 / 12(25)$ & $2 / 27(7)$ & Huang et $\mathrm{al}^{7}$ \\
\hline
\end{tabular}

Note. Patients were classified in to ICU and non-ICU patients instead of nonsurvivors and survivors in the study by Huang et al. ${ }^{7}$

clinical guidelines in China. However, little attention has been given to secondary bacterial and fungal infections, and a standardized diagnostic process remains unavailable. A few challenges exist in diagnosing secondary infection in COVID-19 patients. Although it can be difficult to distinguish bacterial or fungal infection and existing viral pneumonia based on clinical and radiological appearance, microbiological examination can add great value to diagnoses, especially sputum culture. However, this approach can pose significant risks to biosample collectors and laboratory technicians processing samples from COVID-19 patients because the virus is transmitted via virus-laden aerosols in addition to respiratory droplets and direct contact. ${ }^{9}$ Thus far, no standardized personal protection equipment (PPE) has been recommended in the guidelines in China for healthcare workers who process bacterial and fungal cultures. ${ }^{10}$ Other problems include insufficient laboratory biosafety conditions and PPE shortages. These conditions have led to most hospitals to decide not to carry out routine microbiological examination in COVID-19 patients, which undermines the diagnosis and treatment of secondary infection.

Clinical data regarding bacterial and fungal infections are valuable in guiding evidence-based treatment of COVID-19. Thus, we call for strengthening the investigation of secondary infection and/ or coinfection in COVID-19 patients without risking laboratory staff safety. Health authorities and academic organizations need to include a practical diagnostic process for determining bacterial and fungal infection in COVID-19 patients. Furthermore, the biosafety requirements for COVID-19 microbiological laboratory staff should be issued, and personal protection guidelines for microbiological laboratory staff should be clear. Qualified medical institutions need to be encouraged to carry out necessary microbiological examinations. Thus, we will be able to study bacterial or fungal infections in COVID-19 patients in the following aspects: epidemiology (eg, infection sites, incidence rates, epidemic characteristics, risk factors, etc); pathogens and their drug sensitivity results, thus providing the theoretical and factual evidence for precise treatment; accurate prevention and control of infection complications; and effective reduction of the mortality of COVID-19 patients.

\section{Acknowledgments.}

Financial support. This study was funded by the Emergency Project of Prevention and Control for COVID-19 of Central South University (grant no. 160260003).

Conflicts of interest. All authors report no conflicts of interest relevant to this article.

\section{References}

1. COVID-19 situation report-73. World Health Organization website. https:// www.who.int/docs/default-source/coronaviruse/situation-reports/20200402sitrep-73-covid-19.pdf?sfvrsn=5ae25bc7_2. Published 2020. Accessed April 7, 2020.

2. Zhou F, Yu T, Du R, et al. Clinical course and risk factors for mortality of adult inpatients with COVID-19 in Wuhan, China: a retrospective cohort study. Lancet 2020. doi: 10.1016/S0140-6736(20)30566-3.

3. Chertow DS, Memoli MJ. Bacterial coinfection in influenza: a grand rounds review. JAMA 2013;309:275-282.

4. MacIntyre CR, Chughtai AA, Barnes M, et al. The role of pneumonia and secondary bacterial infection in fatal and serious outcomes of pandemic influenza a(H1N1)pdm09. BMC Infect Dis 2018;18:637.

5. Zheng Z, Chen R, Li Y, et al. The clinical characteristics of secondary infection of lower respiratory in severe acute respiratory syndrome. Chin J Respir Crit Care Med 2003;2:270-274.

6. Rijnders B, Schauwvlieghe A, Wauters J. Influenza-associated pulmonary aspergillosis: a local or global lethal combination? Clin Infect Dis 2020. doi: 2020.10.1093/cid/ciaa010.

7. Huang C, Wang Y, Li X, Ren L, Zhao J, et al. Clinical features of patients infected with 2019 novel coronavirus in Wuhan, China. Lancet 2020. doi: 10.1016/S0140-6736(20)30183-5.

8. Yang X, Yu Y, Xu J, Shu H, Xia J, et al. Clinical course and outcomes of critically ill patients with SARS-CoV-2 pneumonia in Wuhan, China: a single-centered, retrospective, observational study. Lancet Respir Med 2020. doi: 10.1016/S2213-2600(20)30079-5.

9. Prevention and control program of the novel coronavirus pneumonia, sixth edition. National Health Commission of the People's Republic of China website. http://www.nhc.gov.cn/jkj/s3577/202003/4856d5b0458141fa9f3768 53224d41d7/files/4132bf035bc242478a6eaf157eb0d979.pdf. Published 2020. Accessed April 7, 2020.

10. Laboratory biological safety guidelines for novel coronavirus. National Health Commission of the People's Republic of China website. http://www.nhc.gov. cn/xcs/zhengcwj/202001/0909555408d842a58828611dde2e6a26.shtml. Published 2020. Accessed April 7, 2020. 